\title{
Microoganism Identification
}

National Cancer Institute

\section{Source}

National Cancer Institute. Microoganism Identification. NCI Thesaurus. Code C132416.

The determination of the type of microorganism in a biological sample. 